\title{
STIL wt Allele
}

National Cancer Institute

\section{Source}

National Cancer Institute. STIL wt Allele. NCI Thesaurus. Code C101127.

Human ST IL wild-type allele is located in the vicinity of $1 \mathrm{p} 32$ and is approximately $64 \mathrm{~kb}$ in length. This allele, which encodes SCL-interrupting locus protein, is involved in signaling that promotes cellular proliferation and modulates embryonic development. A chromosomal deletion at 1 p32 between this gene and the TAL1 gene is associated with T-cell acute lymphoblastic leukemia. Mutation of the gene is associated with microcephaly primary type 7 . 